\title{
General warrants, thematic warrants, bulk warrants: property interference for national security purposes

\author{
Paul F SCOTT*
}

Lecturer in Law, School of Law, University of Glasgow

\begin{abstract}
This paper considers the powers of property interference under the Intelligence Services Act 1994 as they have been employed for the purpose of 'equipment interference' or 'hacking'. It discusses in particular the granting of 'thematic warrants' under the relevant provisions, considering them in the specific context of the common law jurisprudence on 'general warrants'. It argues that the national security context has seen the traditional common law suspicion of property interference evaded but shows that that the implications of that fact are felt also outside the national security context. It then considers these matters in relation to the new powers of equipment interference found in the Investigatory Powers Act 2016.
\end{abstract}

Keywords: property; equipment interference; general warrants; bulk warrants; national security; hacking.

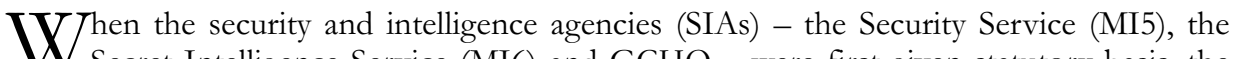
W Secret Intelligence Service (MI6) and GCHQ - were first given statutory basis, the primary power granted to them by statute (the Security Service Act 1989 (the 1989 Act) and the Intelligence Services Act 1994 (ISA 1994/the 1994 Act)) was that of interfering with property. ${ }^{1}$ This article considers the nature of and limits to that power in light of the decision of the Investigatory Powers Tribunal (IPT) relating to computer network exploitation (CNE) (i.e. hacking, now often described as equipment interference (EI)) and the changes to the regime of property interference contained in the Investigatory Powers Act 2016 (IPA 2016/2016 Act). Treatment of these matters takes place with reference to the British constitution's commitment to the value of private property rights and its suspicion of general warrants, as demonstrated most directly by the body of late eighteenth-century case law resulting from attempts to suppress seditious publications, ${ }^{2}$ as well as the modern categories of 'thematic' and 'bulk' warrants. The article shows how the national security origins of the relevant powers have seen the common law's usual suspicion of property interferences fail to create a meaningful obstacle to their exercise, but also that, due to these powers' availability in relation to serious crime, the consequences of that failure

\footnotetext{
* Lecturer in Public Law, University of Glasgow, paul.scott@glasgow.ac.uk. I thank Bernard Keenan, Adam Tomkins and Marta Iljadica for very helpful comments on earlier drafts and discussion of the issues raised by this paper.

1 Security Service Act 1989, s 3 (now repealed); ISA 1994, ss 5-7.

2 Amongst them: Entick v Carrington (1765) 2 Wils 275, (1765) 19 St Tr 1029; Wilkes v Wood (1763) Lofft 1, 98 ER 489; Money v Leach (1765) 3 Burr 1742, 97 ER 1075; Huckle v Money (1763) 2 Wils KB 206, 95 ER 768.
} 
leak out of the national security context. Though the 2016 Act clarifies the law surrounding EI it does so while expanding significantly the powers in question. And, because that Act preserves the powers of property interference under the 1994 Act - and in fact extends their availability to MI6 and GCHQ - the possibility of evading the safeguards which exist on those powers' use may in fact be increased rather than diminished. Finally, there remain important questions about the compatibility of property interferences - and the regimes which govern them - with the European Convention on Human Rights (ECHR).

\section{General warrants}

In their analysis of the Security Service Act 1989, ${ }^{3}$ Ian Leigh and Laurence Lustgarten addressed the system implemented by that statute which allowed for the authorisation, by ministers via warrant, of 'entry on or interference with property', ${ }^{4}$ conferring on those who acted under such a warrant both criminal and civil immunity. ${ }^{5}$ The relevant section of the Act, the authors suggested, 'amounts to statutory authorisation of ministerial general warrants for reasons of state necessity of the kind which the common law disapproved of in the celebrated case of Entick $v$ Carrington'. ${ }^{6}$ The decision in Entick, therefore, 'must now more than ever be regarded as an anachronism of interest mainly to constitutional historians'. 7 After that aspect of the 1989 Act was superseded by the ISA 1994, a redefinition of the functions of the Security Service (and so of its powers under the 1994 Act $)^{8}$ was described by Murray Hunt and Peter Duffy as 'tantamount to the statutory repeal of Entick $v$ Carrington, reversing centuries of common law tradition on the respective roles of courts and executive in relation to the issuing of warrants'. ${ }^{9}$ Each references the most famous of the late eighteenth-century cases relating to the legality of general warrants (though not one in which the warrant at issue was one which was truly general in the sense of failing to specify the person(s) against whom it was to be executed). ${ }^{10}$ The Earl of Halifax had granted the King's messengers (including the eponymous Nathan Carrington) a warrant to 'to seize and apprehend' John Entick 'and to bring, together with his books and papers, in safe custody before me to be examined'. ${ }^{11}$ Lord Camden, Chief Justice of the Common Pleas, was called upon to consider a number of questions. That which he identified as most interesting related to the legality of the warrant, for:

... if this point should be determined in favour of the jurisdiction, the secret cabinets and bureaus of every subject in this kingdom will be thrown open to the search and inspection of a messenger, whenever the secretary of state shall think fit to charge, or even to suspect, a person to be the author, printer, or publisher of a seditious libel. ${ }^{12}$

To interfere with property is a prima facie trespass which if it is not to be unlawful must have clear legal authority (authority which one would expect to be 'clear in proportion as the

3 Ian Leigh and Laurence Lustgarten, 'The Security Service Act 1989' (1989) 52 Modern Law Review 801.

4 Security Service Act 1989, s 3.

5 Ibid s 3(1).

6 Leigh and Lustgarten (n 3) 826.

7 Ibid.

8 Carried out by the Security Service Act 1996.

9 Murray Hunt and Peter Duffy, 'Goodbye Entick v Carrington: The Security Service Act 1996' (1997) European Human Rights Law Review 11.

10 Entick v Carrington (1765) 19 St Tr 1029. On that case, see generally Adam Tomkins and Paul Scott (eds), Entick $v$ Carrington: 250 Years of the Rule of Law (Hart 2015).

11 (1765) 19 St Tr 1029, 1034.

12 Ibid 1063. 
power is Exorbitant'). ${ }^{13}$ Emphasising the special status of one's private property (and in particular one's papers), Lord Camden held that there was no such authority in English law:

Papers are the owner's goods and chattels: they are his dearest property; and are so far from enduring a seizure, that they will hardly bear an inspection and though the eye cannot by the laws of England be guilty of a trespass, yet where private papers are removed and carried away, the secret nature of those goods will be an aggravation of the trespass, and demand more considerable damages in that respect. Where is the written law that gives any magistrate such a power? I can safely answer, there is none . . ${ }^{14}$

Neither the history of government practice since the revolution of 1689,15 nor a bare consideration of the utility of such a power, ${ }^{16}$ sufficed to justify what the law did not explicitly permit. Nor did the invocation of state necessity justify an interference with property for which there was no legal authority: 'the common law does not understand that kind of reasoning, nor do our books take notice of any such distinctions' ${ }^{17}$ As well as testifying to the common law's commitment to a requirement of legality, Entick stands also for the rejection of national security exceptionalism.

Similar statements as to the harmful effects of general warrants are found in other cases of the era, but in many of which the warrant, rather than identifying its subject, purported to empower the seizure of the 'authors, printers and publishers' of the seditious material and of 'their papers'. Both forms of generality - generality as to persons and generality as to property - met with displeasure from the courts. In Entick, Camden noted that there was no 'pretence' that:

. . . the word 'papers' here mentioned ought in point of law to be restrained to the libellous papers only. The word is general, and there is nothing in the warrant to confine it; nay, I am able to affirm, that it has been upon a late occasion executed in its utmost latitude: for in the case of Wilkes against Wood, when the messengers hesitated about taking all the manuscripts, and sent to the secretary of state for more express orders for that purpose, the answer was, 'that all must be taken, manuscripts and all.' Accordingly, all was taken, and Mr. Wilkes's private pocket-book filled up the mouth of the sack. ${ }^{18}$

In Wilkes $v$ Wood itself Camden said of the power to issue general warrants that '[i]f such a power is truly invested in the Secretary of State and he can delegate this power, it certainly may affect the person and property of every man in this kingdom and is totally subversive of the liberty of the subject'. ${ }^{19}$ These cases amount to a clear rejection by the common law of interferences with property which neither specify the person whose property is to be subject to interference (effectively leaving the sufficiency of the evidence against any given individual to be determined by those executing the warrant rather than those granting it) ${ }^{20}$ nor identify the specific property to be interfered with.

13 Ibid 1065-6.

14 Ibid 1066

15 Ibid 1067-73.

16 Ibid 1073-4.

17 Ibid 1073.

18 Ibid 1065

19 Wilkes $v$ Wood (n 2) 498.

20 In Money $v$ Leach, Lord Mansfield said that 'it is not fit, either upon reasons of policy or sound construction of law, that, where a man's being confined depends on an information given, it should be left to the officer to ascertain the person': Money v Leach (1765) 1 Bl 555, 96 ER 320, 323. The same point is made by Blackstone in his Commentaries on the Laws of England, IV, 288. 
Entick (which we, following Leigh and Lustgarten, and Hunt and Duffy, can take as shorthand for the general warrant cases generally) is not usually treated as having laid down or attested to a rule which is special to the context of property, ${ }^{21}$ but one which applies wherever the state wishes to interfere with an interest protected by law (whether public or private). ${ }^{22}$ It applies, like Wade's definition of the prerogative, to acts which alter legal rights and obligations: ${ }^{23}$ for those which do not, no legal authority is required. ${ }^{24}$ Nevertheless, the right to property is given special status in Entick, as in the common law as a whole, ${ }^{25}$ which demands legal authority for interferences with property, for the redefinition of property rights and for deprivations thereof. ${ }^{26}$ Reflecting Lord Camden's belief that 'one should naturally expect that the law to warrant it should be clear in proportion as the power is exorbitant', these things will require an authority which not merely exists but which is suitably explicit (the rule now known as the principle of legality). ${ }^{27}$ Similarly, if property is to be expropriated without compensation, that too must be made sufficiently unambiguous that we can be sure that the relevant 'political price' has been paid within the parliamentary process. ${ }^{28}$ From one point of view then, when Entick is described as having been rendered a 'constitutional anachronism' or having been subject to 'statutory repeal', we encounter a blatant misunderstanding of that case, which speaks only of the need for authority and the fact that the common law does not provide such authority. It is implicit in the judgment in Entick - as it is (and must be) in the various other judgments relating to the right to property at common law - that the interferences inherent in the concept of a general warrant might plausibly be authorised by (a suitably unambiguous) statute. In this sense no statute could ever 'repeal' Entick, but only ever affirm it (and its limits) by providing the sort of authority Entick holds to be required. Nevertheless, statutory regimes for interference with property might accord with the spirit of the general warrant cases to either a greater or lesser degree.

\section{National security, property interference and 'thematic' warrants}

As noted above, one of the potential bases of a power of property interference argued for in Entick was 'state necessity', which we would understand in contemporary parlance to include - perhaps exclusively, but certainly above all else - national security. Powers of property interference for crime-fighting purposes are contained in both the Police and Criminal Evidence Act 1984 (PACE 1984) and the Police Act 1997.29 Though the former is more intrusive than the latter (not limiting the forms of property interference which might take place) each provides important safeguards for certain categories of material,

21 But see Keith Ewing, 'The Politics of the British Constitution' [2000] Public Law 405, 408. For a discussion of Entick in the context of a right to property, see Paul Scott, 'Entick $v$ Carrington and the Legal Protection of Property', in Tomkins and Scott (n 10). The case is placed in its national security context by Tom Hickman in his 'Revisiting Entick v Carrington: Seditious Libel and State Security Laws in Eighteenth-Century England' in the same volume.

22 See the discussions in Scott (n 21) and the chapters by Tomkins and Endicott in Tomkins and Scott (n 10).

23 For which, see H W R Wade, Constitutional Fundamentals (Stevens \& Sons 1980) 47-9 and 'Procedure and Prerogative in Public Law' (1985) Law Quarterly Review 180, 190-4.

24 On the rule of law implications of the purely administrative powers of the Crown (which the author calls its 'ordinary powers'), see Adam Perry, 'The Crown's Administrative Powers' (2015) 131 Law Quarterly Review 652.

25 See Scott (n 21) and Ewing (n 21). See also Thomas Poole, 'The Constitution and Foreign Affairs' (2016) 69 Current Legal Problems 1, contrasting the treatment of property in Entick with that in Secretary of State in Council of India v Kamachee Boye Sahaba (1859) 15 ER 9.

26 Scott (n 21) 147-55.

$27 \mathrm{R} v$ Secretary of State for the Home Department, exp Simms [2000] 2 AC 115.

28 Scott (n 21) 148-9.

29 PACE 1984, ss 8-23; Police Act 1997, Part III. 
including journalistic material and that subject to legal privilege. ${ }^{30}$ Modern law provides in the context of national security a distinct suite of powers of property interference. It was not always thus. Lord Denning, in his report on the Profumo Affair, made public for the first time the Directive, issued by Home Secretary David Maxwell-Fyfe, which defined the role of the Security Service and, in the absence of true legal regulation, governed its actions until the late 1980s. He also stated, emphatically, its legal position:

The Security Service in this country is not established by Statute nor is it recognised by Common Law ... The members of the Service are, in the eye of the law, ordinary citizens with no powers greater than anyone else, they have no special powers of arrest such as the police have. No special powers of search are given to them. They cannot enter premises without the consent of the householder, even though they may suspect a spy is there. ${ }^{31}$

This latter statement was rendered false by the enactment of the Security Service Act 1989, which permitted the Secretary of State to issue, on request of the agency created by that Act (MI5), a warrant permitting the taking 'of such action as is specified in the warrant in respect of any property so specified'. ${ }^{2}$ 'Those actions which might be taken in relation to property are neither limited nor illustrated by the provision in question. The theme of property interference provides the first link back from the exigencies of national security to the general warrant cases. A second is that these warrants are granted not by a judge, but by a minister. If authorised by a warrant, no 'entry on or interference with' property was unlawful. ${ }^{33}$ A warrant could be issued where the Secretary of State thought the action in question necessary in order to acquire information which was 'likely to be of substantial value in assisting the Service to discharge any of its functions' 34 and which could not otherwise be obtained, and that suitable arrangements were in place to ensure the confidentiality of the information thus obtained. ${ }^{35}$ The functions in question were, originally, 'the protection of national security and, in particular, its protection against threats from espionage, terrorism and sabotage, from the activities of agents of foreign powers and from actions intended to overthrow or undermine parliamentary democracy by political, industrial or violent means' and the safeguarding of 'the economic well-being of the United Kingdom against threats posed by the actions or intentions of persons outside the British Islands'. ${ }^{36}$ Neither 'national security' nor 'economic wellbeing' has ever been given statutory definition, ${ }^{37}$ leading to suggestions that the limitation of the Security Service's powers by reference to their functions (which continues to this day) is not a meaningful one. ${ }^{38}$

30 PACE 1984, ss 9-14 and Schedule 1; Police Act 1997, ss 97-100.

31 Lord Denning's Report (Cmnd 2152 1963) [273].

32 Security Service Act 1989, s 3(2). For the background to the 1989 Act, see Leander $v$ Sweden (1987) 9 EHRR 433 and, in the UK context, Hewitt and Harman $v$ UK (1992) 14 EHRR 657. The ability of the 1989 Act to ground a justified interference with the ECHR was established by Esbester $v$ UK (1994) 18 EHRR CD72 .

33 Security Service Act 1989, s 3(1).

34 Ibid s 3(2)(a)(i).

35 Ibid s 3(2)(b).

36 Ibid s 1. To these has been added the support of police authorities in the prevention and detection of serious crime (s 2(4)), on which see below.

37 In Secretary of State for the Home Department $v$ Rehman [2001] UKHL 47, Lord Hoffman said (at [50]) that 'there is no difficulty about what "national security" means. It is the security of the United Kingdom and its people.' But, he added, that "the question of whether something is "in the interests" of national security is not a question of law. It is a matter of judgment and policy.'

38 Hunt and Duffy (n 9) 15-16. 
While, for the reasons given above, a statute cannot conflict with - but only affirm - the rule in Entick, it remains the case that a statute authorising interferences with property might either conform to or offend against the spirit of the general warrant cases. Leigh and Lustgarten considered the 1989 Act to exemplify the latter possibility, identifying as objectionable in particular the absence of excluded categories of material (such as under PACE 1984), the failure to limit the sorts of interferences which might take place, and the fact that the 1989 Act did not require the Service to identify 'the property to be searched or interfered with (and how often), the persons who are targets, or the type of information which it is hoped to discover'. ${ }^{39}$ 'The most important of their points - the supposed absence of any requirement to identify the property to be interfered with - seems (on the face of the 1989 Act) contestable, at the very least. The formulation in s 3 of 'any property so specified' - where 'so specified' is a reference back to 'specified in the warrant' - seems to require that a certain level of detail is included. Although exactly what that level of detail might be contested, that phrasing seems sufficiently demanding as to call into question the implication, carried by invocations of Entick $v$ Carrington, that warrants under the 1989 Act were equivalent to general warrants, for a truly general warrant - one which does not specify the person nor the property to which it applies - would (on this reading) have been ultra vires the statute and acts done under it would therefore be capable of giving rise to civil (and perhaps also criminal) liability. When the powers under the 1989 Act were superseded by the ISA 1994, to the reference to interferences with property was added a power to interfere with wireless telegraphy. ${ }^{40}$ The use of the relevant powers were no longer defined solely with reference to the functions of MI5 but also with reference to the functions of the newly statutorily established MI6 and GCHQ, ${ }^{41}$ warrants to whom would be granted by the Foreign Secretary rather than the Home Secretary. The requirements for the granting of a warrant were modified in number of ways, as they were again by the Regulation of Investigatory Powers Act 2000 (RIPA 2000). The 1994 Act, however, retained (and retains to this day) the wording of the 1989 Act ('of such action as is specified in the warrant in respect of any property so specified'), the interpretation of which is vital to the question of whether warrants are permitted here which are reasonably compared to the sort held in Entick to have no existence at common law. Once again, the plain meaning of the words seems on its face to require that the property be identified to a relatively high degree of specificity within a warrant if the interference is to be intra vires the 1994 Act. These national security warrants should have been general neither as to the persons to whom, nor as to the property to which, they applied, and the fact of ministerial authorisation was not itself sufficient for the 1989 Act (nor the equivalent provisions of the 1994 Act) to render Entick a 'constitutional anachronism'. Though significantly broader than the powers of property interference under, say, PACE 1984, the powers in question might be (more or less plausibly) justified by reference to the more limited and exceptional context in which they are available.

It is therefore both surprising and concerning that the Intelligence Services Commissioner (ISC), in his 2014 report, observed that he had 'expressed concerns about the use of what might be termed "thematic" property warrants' issued under this provision. ${ }^{42}$ Though thematic warrants are not formally defined (and their use does not seem to have been acknowledged or explained prior to the publication of that report), they

39 Leigh and Lustgarten (n 3) 825.

40 ISA 1994, s 5(1).

41 Ibid, ss 1, 3 and 5(2).

42 Rt Hon Sir Mark Waller, Report of the Intelligence Services Commissioner for 2014 (HC 225, 2015) 18. The Commissioner accepted that the interpretation of the various agencies was 'very arguable' and stated too that he could 'see in practical terms the national security requirement'. 
can be understood as warrants which identify the persons and property to whom they apply by virtue of a theme which connects them, rather than their specific identity. Though such warrants are - as regards the interception of communication - available under RIPA $2000,{ }^{43}$ that possibility is created by the peculiar definition therein of 'person', which the Act states to include 'any organisation and any association or combination of persons' ${ }^{44}$ Although that legislative grounding is problematic in its obliqueness, there is no equivalent basis for thematic warrants in the context of section 5 of the 1994 Act.

\section{Proceedings in the IPT}

The correct interpretation of the key phrase within the 1994 Act was the subject of consideration by the IPT in Privacy International $v$ Foreign Secretary (Privacy/GreenNet), ${ }^{45}$ relating to the legality of $\mathrm{CNE}$, the avowal of the use of which by GCHQ happened only during the proceedings and led to the publication of an EI Code of Practice. ${ }^{46} \mathrm{CNE}$ is carried out in accordance with warrants under s 5 of the 1994 Act and authorisations under s 7 (discussed further below). The Code, as brought into force, ${ }^{47}$ does not require that an application for a section 5 warrant contain specific details of the property to be interfered, but instead that it must contain, inter alia, 'the identity or identities, where known, of those who possess or use the equipment that is to be subject to the interference' and 'sufficient information to identify the equipment which will be affected by the interference'. ${ }^{48}$ In holding that the approach taken by the Code was a lawful one, because the statutory language was to be understood as requiring only that the warrant to be as specific as possible in relation to the property to be covered by the warrant . . . so that the property to be covered is objectively ascertainable, ${ }^{49}$ the tribunal declared that:

Eighteenth Century abhorrence of general warrants issued without express statutory sanction is not in our judgment a useful or permissible aid to construction of an express statutory power given to a Service, one of whose principal functions is to further the interests of UK national security, with particular reference to defence and foreign policy. The words should be given their natural meaning in the context in which they are set. ${ }^{50}$

It is not the case, then, that the property to which a warrant applies need be specified. Instead, the property should be 'so defined, whether by reference to persons or a group or category of persons, that the extent of the reasonably foreseeable interference caused by the authorisation of $\mathrm{CNE}$ in relation to the actions and property specified in the warrant can be addressed'. ${ }^{51}$ This conclusion was justified by reference both to the unconvincing - distinction between the term 'specified' as used in the 1994 Act and to the allegedly stronger statutory phrasing of 'particular documents specified' in the Evidence (Proceedings in Other Jurisdictions) Act 1975,52 as well as to the fact that 'specified' in the 1994 Act was used in relation not just to 'property' but also to 'action'

43 Such warrants were first avowed in the Intelligence and Security Committee's report, Privacy and Security: $A$ Modern and Transparent Legal Framework (HC 1075, 2015) [42]-[45].

44 RIPA 2000, s 81(1).

45 Privacy International $v$ the Secretary of State for Foreign and Commonwealth Affairs [2016] UKIP Trib 14_85-CH (hereinafter 'Privacy/GreenNet').

46 See the Draft EI Code of Practice (February 2015) and the EI Code of Practice (January 2016).

47 By the Equipment Interference (Code of Practice) Order 2016, SI 2016/38 (14 January 2016).

48 EI Code of Practice (January 2016) [4.6].

49 Privacy/GreenNet [47].

50 Ibid [37].

51 Ibid [38] (emphasis removed).

52 Ibid [39]. 
and 'wireless telegraphy' and therefore 'cannot have meant anything more restrictive than "adequately specified". 53

As a result of this reasoning, though the 1994 Act seems on its face to accord with the spirit of Entick $v$ Carrington, as interpreted by the IPT it offends against that spirit, empowering - in the tribunal's own example - the issuing of warrants which:

... permit GCHQ to interfere with computers used by members, wherever located, of a group whose activities could pose a threat to UK national security, or be used to further the policies or activities of a terrorist organisation or grouping, during the life of a warrant, even though the members or individuals so described and/or of the users of the computers were not and could not be identified when the warrant was issued. ${ }^{54}$

Warrants under s 5, that is, may therefore be thematic, identifying specifically neither the property in question nor those to whom it belongs. Crucially absent from the IPT's reasoning is a direct consideration of Lord Camden's point that 'one should naturally expect that the law to warrant it should be clear in proportion as the power is exorbitant', a principle of statutory interpretation repeatedly reaffirmed by the courts in the context of fundamental rights under the name of the principle of legality and whose robust application by the courts to interferences with private property would in other circumstances be entirely inevitable. ${ }^{55}$ If the principle of legality is to perform the constitutional role assigned to it, it must mean not only that some interference with fundamental rights is clearly foreseen by the relevant statute (which is indeed true of s 5 of the 1994 Act) but that the interference which is foreseen be of the nature and extent which the statute is claimed to permit. That does not seem to be the case with $\mathrm{s} 5$ and it is doubtful whether it is even the case, as the IPT suggests, that the 'natural meaning' of the words is such as to permit interferences with property on the terms it specifies. ${ }^{56}$ Entick $v$ Carrington was proof not only of the common law's adherence to the rule of law, but of the inability of national security concerns (in the form of 'state necessity') to override the need to demonstrate legal authority. Here, national security seems to operate as an exception not to the general requirements of the rule of law, but to the interpretive approach which has grown up around it, as evidenced by the otherwise gratuitous reference to the functions of GCHQ in the passage asserting the irrelevance to the question of the general warrant cases. ${ }^{57}$ It is highly unlikely that equivalent legislation aimed at other public interest ends would be approached with the generosity that the IPT demonstrates. It would be one thing to create an explicit rule of the sort that the IPT implicitly puts into effect here - to say that the principle of legality has no application where the security of the state is at issue - but to claim that the natural meaning of the statutory language ('property so specified') is such as to permit warrants of the breadth envisaged does not convince. That there is no requirement that they be foreign-focused (as bulk acts of interception under RIPA 2000 were required to be $)^{58}$ nor that the information

53 Ibid [44].

54 Ibid [65].

$55 \mathrm{R} v$ Secretary of State for the Home Department, exp Simms (n 27). See also Scott (n 21).

56 Privacy/GreenNet [37].

57 This interpretative exceptionalism would seem also to be at odds with the approach of the Supreme Court in HM Treasury $v$ Abmed [2010] UKSC 2, where the principle of legality was applied - in the context of the freezing of terrorist assets - in holding that orders made under the United Nations Act 1948 were ultra vires that statute, the language of which was insufficiently explicit to justify interferences with fundamental rights.

58 RIPA 2000, ss 8(4) and (5), disapplying the requirement that a warrant identify a single person or set of premises as the target where the warrant authorised 'the interception of external communications in the course of their transmission by means of a telecommunication system'. 
thus acquired be examined only according to a requirement of necessity (ditto) ${ }^{59}$ makes the phenomenon of thematic warrants under the 1994 Act particularly concerning. ${ }^{60}$

\section{Serious crime and the danger of national security exceptionalism}

What had originally prompted Hunt and Duffy to suggest that Entick had been 'statutorily repealed' was not, however, the powers contained in the 1994 Act themselves, but the modification made in 1996, when the Security Service was given the new, additional function of acting in support of the activities of police forces and other law enforcement agencies in the prevention and detection of serious crime'. ${ }^{61}$ Given that the availability of warrants is defined with reference to the functions of the SIAs, the grant of a new function implies a greater availability of warrants. MI6 and GCHQ could, under the 1994 Act as enacted, apply for warrants on the basis of their functions relating to serious crime only where the property in question is outside the British Islands; only property interferences taking place in pursuit of their other functions could relate to property within the British Islands. ${ }^{62}$ There was therefore a further recognition of the distinction between national security purposes and crime-fighting ones: the most intrusive powers were available (in the British Islands) only in the former context. Following the changes made by the 1996 Act, by contrast, MI5 might apply for a warrant authorising interference with property in the British Islands for crime-fighting purposes. The new provisions inserted into the 1994 Act by the 1996 Act purported to restrict the use of these powers, providing for an ostensibly limited understanding of serious crime - that which either 'involves the use of violence, results in substantial financial gain or is conduct by a large number of persons in pursuit of a common purpose' or involves offences on conviction for which a person of 21 with no previous convictions could reasonably be expected to be sentenced to three or more years in prison ${ }^{63}$ (a limit which did not apply to the work of MI6 and GCHQ in relation to serious crime abroad). ${ }^{64}$ Notwithstanding this restriction, the effect of the 1996 Act was to make available significant powers of property interference in relation to matters of ordinary criminal law. As it was put by Lord Browne-Wilkinson in the debate on the Bill:

So far as I can see, what has happened casually, in a House which has remarkably few people in it, is to carry over from the national security, twilight, Smiley's People world, into the every day life of policing, excessive powers of a kind that this country has always resisted and which are basic to its freedom. ${ }^{65}$

59 Ibid s 16.

60 Indeed, the use of thematic warrants is sufficiently frequent that the ISC has recommended that the SIAs develop a method of recording their reliance on such warrants in particular operations, something the 1994 Act does not require: Rt Hon Sir Mark Waller, Report of the Intelligence Services Commissioner for 2015 (HC 459, 2015) 17-88.

61 By the Security Service Act 1996, modifying s 1(4) of the Security Service Act 1989. Of the 1996 Act, Home Office Minster Baroness Blatch said that 'the Government's reading of the position is that the celebrated case of Entick $v$. Carrington established the important principle that a person's house should not be entered without lawful authority ... Authorisation by the Secretary of State in accordance with this legislation represents lawful authority. All that has changed is that the Security Service will now be able to apply for property warrants in pursuance of its new statutory function relating to serious crime, in addition to its existing national security and economic well-being functions.' HL Deb 8 July 1996, vol 574, cols 81-2.

62 ISA 1994, s 5(3).

63 Ibid s 5(3A) and (3B). The same formulation is used in the Police Act 1997, s 93(4).

64 MI5 can also apply for warrants to do things which fall within the functions of MI6 or GCHQ rather than MI5 itself, but not where the purpose of the action is the prevention and detection of serious crime, preventing it from using its ability to substitute for the other agencies to bypass the limits upon its own actions: ISA 1994, ss 4 and 5.

65 HL Deb 27 June 1996, vol 573, cols 1043-4. 
Hunt and Duffy's concerns with this new regime of property interferences within the British Islands in relation to serious crime were twofold. The first related to the definition of serious crime which, though it purported to limit the availability of domestic warrants for crime-fighting purposes, in fact amounted to a considerable expansion of powers of property interference so as to include, for example, 'virtually all investigations by Customs and Excise and the Inland Revenue' and 'industrial disputes and political demonstrations'. ${ }^{66}$ 'This conclusion seems correct and yet the offending criteria remain in place, meaning that the powers of property interference in the British Islands are not restricted to the context of national security or the fight against terrorism, but in fact exist in relation to much of which falls - or should fall - in the province of the ordinary police or the National Crime Agency. Powers which were originally justified by reference to the special exigencies of national security became available outside of the context. And so when the IPT interpreted s 5 of the 1994 Act as not requiring a high degree of specification in the identification of property to be interfered with, that decision had the effect of creating a broader power of property interference also in the context of 'serious crime' - a category which, as we have seen, includes much for which that label is a misnomer. If the IPT's approach might have conceivably been justified on national security grounds, it nevertheless has major implications outside of that context, making thematic warrants available also for crime-fighting purposes. A second concern about the 1996 changes was that the availability of property interference warrants for serious crime purposes allowed the Security Service to bypass the various safeguards which existed on the powers of the police (then primarily under PACE 1984), including the need for judicial rather than executive authorisation and special protections which exist in other statutes for certain types of material - legal, journalistic and so on. In light of the interpretation of s 5 endorsed by the IPT in Privacy/GreenNet, this point too becomes more urgent: section 5 warrants can be used to bypass other powers (and the safeguards which exist upon them) while themselves permitting interferences with property that begin to approach the generality of the warrants against which the common law so resolutely set itself. MI5 may seek and be granted warrants which permit it to interfere with property in the British Islands for crime-fighting purposes without detailing the property which is to be interfered with, so long as the identity of the property is 'objectively ascertainable' from the terms of the warrant.

\section{Authorisations under s 7 of the 1994 Act}

Alongside warrants under s 5 of the 1994 Act, that statute empowers (in s 7) the issuing of 'authorisations' to act outside of the British Islands, extinguishing any civil or criminal liability which might otherwise arise out of 'any act' done by virtue of the authorisation. ${ }^{67}$ They can be given only where the Secretary of State is satisfied: that any acts done under an authorisation are necessary for the discharge of some function of either MI6 or GCHQ;68 that satisfactory 'arrangements' exist to ensure that nothing will be done in reliance on the authorisation beyond what is necessary for the discharge of such a function and that the 'nature and likely consequences' of any acts done in reliance on the authorisation will be reasonable 'having regard to the purposes for which they are carried out'; ${ }^{69}$ and, finally, that suitable arrangements are in place to guard against disclosure of

66 Hunt and Duffy (n 9) 13.

67 As well as ensuring that there exists a formal record of the political authorisation of some act or operation, which cannot for that reason take place without the knowledge and consent of the Foreign Secretary.

68 ISA 1994, s 7(3)(a). Originally, authorisations were available only to MI6; the 1994 Act was amended to make them available to GCHQ by s 116 of the Anti-terrorism, Crime and Security Act 2001.

69 ISA 1994, s 7(3)(b). 
information obtained in this way. ${ }^{70}$ Section 7 illustrates some of the ways in which an authorisation might be framed, including that it might relate 'to a particular act or acts, to acts of a description specified in the authorisation or to acts undertaken in the course of an operation so specified'. ${ }^{71}$ It will be seen from that formulation that $\mathrm{s} 7$ offers up a power which would wholly justify invocation of Entick $v$ Carrington, going far beyond what an eighteenth-century general warrant might have contained - so as to include, for example, acts such as homicide which interfere with the right to life rather than the right to property - and similarly far beyond the thematic warrants under s 5 approved of in Privacy/GreenNet. Two points must be made. The first is the distinction between the 1994 Act's framing of the power to make authorisations (under s 7) and the power to grant warrants (under s 5): in the context of authorisations it was felt necessary by the drafters to clarify the sorts of acts which might be carried out and, in particular, the way in which they might be identified within an authorisation. The drafting of $\mathrm{s} 7$ is therefore sufficiently explicit as to justify the sorts of 'thematic' warrants which the IPT held to be justified by the far more ambiguous s 5 . Section 7 has been drafted so as to overcome the principles of statutory interpretation which mitigate interferences with public law rights; s 5 has not, and yet has been held nevertheless to evade those principles. Authorisations given for acts of a specified type (rather than specific acts) are described as 'class authorisations'. MI6 had eight class authorisations (which 'remove liability under UK law for day-to-day activity undertaken in pursuit of SIS's statutory functions, such as the identification and use of Covert Human Intelligence Sources, Directed Surveillance and interference with, and receipt of, property and documents') in place in $2014 .^{72}$ GCHQ had seven. ${ }^{73}$

A second point relates to the geographic aspect. Both s 5 and s 7 distinguish acts within and outside of the British Islands. ${ }^{74}$ Section 7 applies only outside that area, ${ }^{75}$ while s 5 (as originally enacted) limited the power of property interference for the purpose of preventing or detecting serious crime within the British Islands as compared to its possibility outside that area. On the one hand, this of course reflects the fact that the ECHR, by virtue of its Article 1, extends - in the normal course of events - only to the territory of the contracting parties. ${ }^{76}$ On that basis, the Property Interference Code of Practice did not apply to $\mathrm{s}$ and there is no power to issue codes of practice in relation to that provision. Now, the EI Code of Practice provides that MI6 and GCHQ should 'as a matter of policy apply the provisions of this code in any case where EI is to be, or has been, authorised pursuant to s 7 of the 1994 Act in relation to equipment located outside

70 Ibid s 7(3)(c).

71 Ibid s 7(4).

72 Intelligence and Security Committee (n 43) [233].

73 Ibid [234]. The Intelligence and Security Committee has recommended that ministers be periodically provided with a list of operations carried out under the class authorisations, but no such lists have been kept in the past: [PP].

74 Meaning, by virtue of the Interpretation Act 1978, the 'United Kingdom, the Channel Islands and the Isle of Man'.

75 Subject to an exception permitting the doing of something within the British Islands to 'apparatus' believed to be outside it (or 'in relation to anything appearing to originate from such apparatus' (ISA 1994, s 9 (inserted by the Anti-terrorism, Crime and Security Act 2001)) and another relating to property either mistakenly believed to be outside the British Islands or brought into British Islands after the making of the authorisation (ss 10-14 (inserted by the Terrorism Act 2006)). In both cases, there exists a five-day grace period between becoming aware of the property's presence in the British Islands and ceasing to interfere with it.

76 See on the question of the ECHR's extra-territorial effect, Bankovic v Belgium (2007) 44 EHRR SE5 and AlSkeini v UK (2011) 53 EHRR 18 and, in the domestic courts, Al-Saadoon v Secretary of State for Defence [2016] EWCA Civ 811. 
the British Islands', ${ }^{77}$ but makes that statement of policy 'without prejudice as to arguments regarding the applicability of the ECHR'. ${ }^{78}$ But the geographical distinction might be thought to reflect also a further element of the decision in Entick, whereby it has been taken to establish (or to speak to) the inability of the Crown to justify an otherwise tortious action against a British citizen in Britain by claiming that the act was an 'act of state' to which the Crown's immunity applies. ${ }^{79}$ The 'Crown act of state' tort defence applies only to actions abroad (and possibly, even there, only to non-nationals); 80 its application in the UK possible, if at all, only in relation to acts done to enemy aliens. ${ }^{81}$ To speak of the spirit of Entick $v$ Carrington, then, is to reference an ideal which is necessarily limited in its scope; where the modern statutes authorising property interferences make geographic distinctions, they are in that sense in keeping with rather than at odds with Entick. The changes introduced by the 1996 Act undercut that distinction by making possible broad property interferences in the UK, without the overriding justification of national security considerations. Insofar, then, as the law of property interference reflects an ongoing aversion to general warrants, that aversion applies only to the home jurisdiction and, even there, to a lesser extent than was previously the case.

\section{The compatibility of CNE with the ECHR}

At common law, the absence of legal recognition for the individual's privacy interests meant that legal challenges to what were effectively privacy interferences often took place with reference to the individual's property rights. ${ }^{82}$ Conversely, the fact that the property interference at issue here took place in order to facilitate surveillance meant that the key ECHR issue was that of compatibility with Article 8. In Weber and Saravia v Germany, ${ }^{83}$ the European Court of Human Rights distilled from its own case law six questions which surveillance norms - those the full operation of which cannot be revealed to the public at large without undermining their effectiveness - must answer if they are to avoid abuses of power and meet the requirement of foreseeability implied by 'in accordance with the law'. These are:

... the nature of the offences which may give rise to an interception order; a definition of the categories of people liable to have their telephones tapped; a limit on the duration of telephone tapping; the procedure to be followed for examining, using and storing the data obtained; the precautions to be taken when

77 EI Code of Practice (January 2016) [7.1].

78 Ibid 33, fn 18. Privacy International has, since the IPT gave judgment in Privacy/GreenNet, made an application to the European Court of Human Rights regarding the use of s 7, in which this question can be expected to feature prominently.

79 E C S Wade, 'Act of State in English Law: Its Relations with International Law' (1934) 15 British Yearbook of International Law 98. Collier agrees: J G Collier, 'Act of State as a Defence against a British Subject' (1968) Cambridge Law Journal 102, 111, but see Peter Cane, 'Prerogative Acts, Acts of State and Justiciability' (1980) 29 International and Comparative Law Quarterly 680, 686.

80 See, most recently, the judgment of the Supreme Court in Serdar Mohammed v Secretary of State for Defence [2017] UKSC 1. On the specific point about nationality, see also Nissan v Attorney-General [1970] AC 179.

81 Johnstone v Pedlar [1921] 2 AC 262. On the doctrine generally, see Paul Scott, 'The Vanishing Law of Crown Act of State' (2015) 66 Northern Ireland Legal Quarterly 367.

82 This was the case in Entick, but more obviously so in Malone v Commissioner of Police of the Metropolis (No 2) [1979] Ch 344, in which it was held that the tapping of the applicant's telephone (which had taken place at the post office) was lawful notwithstanding the absence of statutory authority because there was no common law right of privacy to be interfered with, while nothing had been done which was incompatible with his property rights. 
communicating the data to other parties; and the circumstances in which recordings may or must be erased or the tapes destroyed . . ${ }^{84}$

Those same requirements were in Liberty/Privacy (No 1) ${ }^{85}$ applied by the IPT to the various activities of the intelligence agencies whose existence was first alleged on the basis of the Snowden disclosures of $2013^{86}$ and it was not contested in Privacy/GreenNet that they apply also to CNE. ${ }^{87}$ This is an important point: in analogising between property interferences under the 1994 Act and those in the general warrant cases, it can be easy to lose sight of the fact that the interferences in Entick took place openly, while those under the 1994 Act take place in secret and so are rightly assimilated to the secret interception of communication, which if it is to be effective must not be known about by its targets. ${ }^{88}$ Though there is nothing which directly prohibits the use of section 5 warrants to carry out open interferences with property (to which the Weber requirements would not apply), this use would be at odds with the statute and the work of the agencies which make use of it. It will be recalled that the IPT here held that what was required of a section 5 ISA 1994 warrant was that it 'be as specific as possible', so as to permit the Secretary of State to be satisfied as to its legality, necessity and proportionality. Where a warrant fulfils that requirement, the IPT held here, it by definition satisfies the first three of the Weber requirements. ${ }^{89}$

The fourth, fifth and sixth of the Weber requirements cause more difficulty. The IPT had decided in Liberty/Privacy (No 1) that, though (in this particular field) detail of those arrangements preventing powers from being exercised arbitrarily need not be placed in full in the public domain, there must be 'a sufficient signposting of the rules or arrangements insofar as they are not disclosed'. 90 The two criteria that must therefore be met are, first, that '[a]ppropriate rules or arrangements exist and are publicly known and confirmed to exist, with their content sufficiently signposted, such as to give an adequate indication of it' and, second, that those rules or arrangements are 'subject to proper oversight'. ${ }^{91}$ The nature of the political oversight of the SIAs has not varied substantially over time - the relevant bodies are the Intelligence and Security Committee (given statutory basis by the Justice and Security Act 2013) and the ISC, whose work the IPT repeatedly praised. ${ }^{92}$ These oversight mechanisms are, however, retrospective and mostly general. The only relevant legal mechanism - a complaint to the IPT - is retrospective

83 [2008] 46 EHRR SE5.

84 Ibid [95].

85 Liberty v Government Communications Headquarters [2014] UKIP Trib 13_77-H.

86 Eventually holding, in Liberty/Privacy (No 2) [2015] UKIP Trib 13_77-H that, prior to disclosures made as part of the litigation process, certain of those activities had been unlawful.

87 The European Court of Human Rights has emphasised that the 'decisive factor' as to whether or not the requirements developed in the surveillance context apply is 'the level of interference with an individual's right to respect for his or her private life and not the technical definition of that surveillance': RE $v$ UK (2016) 63 EHRR 2.

88 One important distinction, not further discussed herein, is that evidence acquired via CNE is - unlike that acquired via interception - admissible in legal proceedings.

89 [2016] UKIP Trib 14_85-CH, [57]-[59].

90 [2014] UKIP Trib 13_77-H, [41].

91 Ibid.

92 [2016] UKIP Trib 14_85-CH, [65] and [74]. Previously, complaints about the work of the Security Service could be made to the Security Service Tribunal and those about the Intelligence Service to the Intelligence Services Tribunal. There was no right of appeal the decisions of those bodies, while the relevant statutes purported to exclude judicial review of those decisions. Under RIPA 2000, complaints against the intelligence services are within the jurisdiction of the IPT (RIPA 2000, s 65) to the decisions of which the same exclusions apply (s 67(8)). When the Investigatory Powers Act 2016 comes fully into force, this will change. 
and, though not general, relies on an individual having knowledge (or at least suspicion) of action having been taken against him or her, with the Commissioner enjoying no statutory power to refer section 5 warrants to the IPT, nor notify the victim of unlawful acts thereunder. Moreover, the EI Code of Practice was issued only as a result of these IPT proceedings, and so the question of compatibility divides temporally into that of compatibility of the relevant powers since the issuance of that Code and their compatibility prior to that (treated here as relating to the period since the coming into force of the Property Interference Code in August 2009). The IPT held that these further requirements of Weber are indeed complied with by the EI Code of Practice and so, since its coming into force, the regime of CNE had been compatible with the ECHR. ${ }^{93}$ This left open the question of whether that regime before then was Convention-compliant. Not all of the rules relevant to that question are either contained only in the EI Code of Practice or exist 'below the waterline' (in the sense of being publicly acknowledged but not publicly disclosed); also relevant - the IPT claimed - was the work of the ISC and the statutory rules which prohibit the disclosure by GCHQ staff of the (below-thewaterline) arrangements which statute requires to be in place. ${ }^{94}$ Others are contained in the Property Code of Practice, which dates from 2009, and so was in place at the relevant time (and still applies to EI where not impliedly repealed by the EI Code of Practice). ${ }^{95}$ Detail of below-the-waterline arrangements given by the respondents here (some of them a gist of closed material) were held by the IPT to be 'adequate, in the context of the interests of national security, to impose the necessary discipline on GCHQ' and to provide 'adequate protection against arbitrary power'. ${ }^{96}$ And though the existence of the below-the-waterline arrangements in respect of $\mathrm{CNE}$ could not have been made known before the government avowed the use of CNE in 2015, it was foreseeable that hacking as a form of property interference would fall within the range of acts authorised by ss 5 and 7 of the 1994 Act. ${ }^{97}$ As such, though the procedural protection might have been improved (and in fact was, with the coming into force of the EI Code of Practice), whatever inadequacy there was present was insufficient to constitute a breach of the requirements of the ECHR: there was, even prior to the EI Code of Practice, sufficient protection against arbitrary interference. ${ }^{98}$ The IPT emphasised here that to comply with the second grouping of Weber requirements requires 'the provision, particularly in a national security context, of as much information as can be provided without material risk to national security' and that the consequences of a holding of a violation on the basis of 'perceived procedural insufficiency' were such that a holding that the procedural requirements (or their publicity) was amenable to improvement did not necessitate a finding that the unimproved processes were incompatible with the Convention. ${ }^{99}$

This decision seems problematic on a number of levels. The first is on its own terms, whereby there was sufficient protection against arbitrary interference, even when there was no EI Code of Practice, before the use of CNE by the SIAs had been avowed by the government and before the below-the-waterline arrangements disclosed here had been

93 [2016] UKIP Trib 14_85-CH, [70].

94 Ibid [75]-[77].

95 EI Code of Practice (2016), [1.2].

96 [2016] UKIP Trib 14_85-CH, [77].

97 Ibid [81]. This despite the fact that the acts in question were prima facie unlawful by virtue of the Computer Misuse Act 1990. The savings provision of that statute (s 10) was amended, during the litigation period, by the Serious Crime Act 2015. The IPT, at [20], held the amendment to be merely 'clarificatory', with the 1990 Act to be read subject to the powers in the 1994 Act. I am grateful to Bernard Keenan for this point.

98 [2016] UKIP Trib 14_85-CH, [82].

99 Ibid. 
made public. Either the Weber requirements were met or they were not - that is, either the 'minimum safeguards' existed, or they did not - and the IPT, in treating the question as a teleological one, detached from the requirements which feed into it, has impliedly asserted a right to make an overall assessment that is devoid of direct analysis and, for that reason, not amenable to later replication. This conclusion is supported by the fact that it has interpreted the 1994 Act - contrary to the principle of legality which the courts, in the context of unlimited parliamentary competence, have placed at the heart of the constitutional order, as well as several hundred years of common law aversion to warrants of such breadth - to permit interferences with property not themselves individually specified, meaning that the terms upon which property might be interfered with were not, until this case, remotely foreseeable to citizens. Indeed, the decision as to the quality of the law which permits $\mathrm{CNE}$ presumes that the interference with Article 8 enjoys an adequate legal basis. For the reasons given above, that may be true of some property interferences under s 5 of the 1994 Act, but it is not true of those carried out pursuant to thematic warrants. Finally, and taking at face value its holistic and teleological approach, the IPT is curiously vague on the question of how the relevant requirements were fulfilled prior to the publication of the EI Code of Practice and the (partial) disclosure of below-the-waterline arrangements, apart from in its suggestion that those arrangements add nothing material to the contents of the Property Code. The core of its reasoning seems to be found in the reference to the consequences of finding a violation on the basis of 'perceived procedural insufficiency'. ${ }^{100}$ The consequences in question do not include the making of a declaration of incompatibility: the insufficiency was not found in the statute itself, but in the other arrangements, while the IPT does not have the power to make such a declaration and there has been no right of appeal from it to a court which does have such a power. ${ }^{101}$ A finding that the Weber requirements had not been fulfilled, however, might have prompted a vast number of claims of action contrary to s 6 Human Rights Act 1998 (HRA 1998), of a sort that the IPT has been fending off since deciding, in Liberty/Privacy (No 2), that the system by which intercepted material was shared with it by the American National Security Agency had previously been noncompliant with the ECHR. ${ }^{102}$ What we witness is a second sort of national security exceptionalism (less tolerable precisely because it is implemented in a context in which the ECHR already imposes, in the form of Weber requirements, less onerous requirements than apply to Article 8 interferences generally), accompanied here both by a denigration of the importance of procedure and, indeed, a dubious characterisation thereof, widened so as to include quite fundamental issues regarding, for example, the use made of material obtained via CNE.

But even if the decision here were the correct one, developments in Strasbourg tend to undermine the sort of generalised surveillance made possible by the interpretation the IPT gives to the 1994 Act. First, the decision of the Grand Chamber in Zakharov v Russia ${ }^{103}$ - holding that interception warrants must 'clearly identify a specific person to be placed under surveillance or a single set of premises as the premises in respect of which the authorisation is ordered'104 and that an authority authorising surveillance 'must be

100 Ibid.

101 RIPA 2000, s 67(8); HRA 1998, s 4(5). Privacy International sought, without success, judicial review of the IPT's decision here: R (Privacy International) v Investigatory Powers Tribunal [2017] EWHC 114 (Admin). For discussion, see Paul F Scott, 'Ouster Clauses and National Security: Judicial Review of the Investigatory Powers Tribunal' [2017] Public Law 355.

102 See Human Rights Watch v Secretary of State for Foreign and Commonwealth Affairs [2016] UKIP Trib15_165-CH. 103 (47143/06) 39 BHRC 435.

104 Ibid [264]. 
capable of verifying the existence of a reasonable suspicion against the person' subject to surveillance measures ${ }^{105}$ - must apply equally to exercises of the property-interference powers which constitute surveillance. Secondly, in Szabó and Vissy v Hungary, ${ }^{106}$ a Chamber of the Court stated that, while the authorisation of the use of surveillance powers by a non-judicial authority can be compatible with the Convention, the supervision of their use by a 'politically responsible member of the executive, such as the Minister of Justice, does not provide the necessary guarantees' of independence. ${ }^{107}$ The context involved provisions of domestic law which appeared capable of enabling 'strategic, large-scale interception', ${ }^{108}$ distinguishing Szabó from the court's decision in Kennedy $v U K$, where the provisions in RIPA 2000 at issue did not permit the indiscriminate capturing of vast amounts of communications.' ${ }^{109}$ If these elements of the recent case law crystallise as requirements to be met by all surveillance measures, thematic warrants would seem to be compatible with the 1994 Act (as interpreted by the IPT) and yet incompatible with the ECHR. It would, of course, remain possible to evade the requirement by carrying out a property interference that does not constitute surveillance, but such interferences are those where the generality is likely to be of least value to the SIAs - there is little point in being able to target a large and only loosely defined group of people with a single warrant if the interference must be carried out with their knowledge. Instead, the correct route would be to interpret - as required by s 3 HRA 1998 - the powers to issue warrants in a manner compatible with the Convention and so as incapable of grounding a thematic warrant. That is, the interpretive obligation within the 1998 Act would seem likely to mandate a conclusion diametrically opposed to that arrived at via ordinary common law principles of interpretation. This suggests either a remarkable divergence of the two regimes, or, more likely, a flawed application here of the common law's method of protecting fundamental rights.

The ISA 1994, it will be recalled, lacks safeguards in relation to confidential material (unlike PACE 1984 and the Police Act 1997). It was these safeguards (amongst other things) that Hunt and Duffy were concerned that the 1994 Act might be used to evade once the Security Service's functions had been expanded to include that of assisting in the detection and prevention of serious crime. The lack of safeguards in the Property Code had been condemned by the European Court of Human Rights in RE $v U K .^{110}$ It has similarly been accepted by the IPT that since January 2010 the regime under which legally privileged material was intercepted, analysed, used and destroyed was contrary to Article 8, ${ }^{111}$ as it was accepted that the acquisition and use of legally privileged material via CNE was so contrary. 112 The EI Code of Practice, however, addresses the issue of legally privileged material and other confidential material, ${ }^{113}$ providing greater safeguards than are contained even in the revised Property Code. The IPT here held that the new safeguards are sufficient to bring the CNE regime in line with Article 8 as regards legally privileged material. The possibility of using the 1994 Act to evade the safeguards

105 Ibid [277].

106 (2016) 63 EHRR 3.

107 Ibid [77].

108 Ibid [69].

109 (2011) 52 EHRR 4, [160].

110 (2016) 63 EHRR 2, relating to surveillance of solicitor-client conversations, rather than interception or property interference.

111 Belhadj and Others $v$ the Security Service [2015] UKIP TRIB 13_132-8.

112 [2016] UKIP Trib 14_85-CH, [80] and [84], accepting that the concession in Belhadj applies also here.

113 EI Code of Practice (January 2016) 15-20. 
applicable to other interference regimes is therefore belatedly diminished. Like those made above, however, the point is rendered less urgent by the enactment of the IPA 2016.

\section{Property interference under the IPA 2016}

The IPA 2016 creates a new and specific regime for the authorisation of EI of a sort recommended by the ISC in its report into the intrusive capabilities of the SIAs. ${ }^{114}$ Contrary to the ISC's recommendation, ${ }^{115}$ however, the 2016 Act does not create an exhaustive regime for the exercise of all of the relevant powers, but leaves the 1989 and 1994 Acts in place. ${ }^{116}$ The primary form of authorisation is a 'targeted interference warrant' which 'authorises or requires the person to whom it is addressed to secure interference with any equipment for the purpose of obtaining' either communications, equipment data, or other information. ${ }^{117}$ They can be issued only where the Secretary of State considers that the warrant is necessary on certain specified grounds including 'national security' and for 'the purposes of preventing and detecting serious crime',118 that the conduct it authorises is proportionate, 119 that satisfactory arrangements regarding disclosure are in place, ${ }^{120}$ and (except in urgent cases) where it has been approved by one of the new Judicial Commissioners. ${ }^{121}$

Where there was much doubt as regards the 1994 powers, the 2016 Act is entirely explicit in its intention to allow targeted warrants to be 'thematic', relating to, for example, equipment 'belonging to, used by or in the possession of a particular person or organisation', that 'belonging to, used by or in the possession of a group of persons who share a common purpose or who carry on, or may carry on, a particular activity' (or more than one such group, if the interference is part of a single investigation or operation), and equipment 'in a particular location' (or more than one, subject to the same proviso). ${ }^{122}$ There is, therefore, no absolute requirement to specify either the persons or the property with whom these interferences will be carried out - 'general warrants' are in this way, and for one specific form of property interference, explicitly revived and beyond the specific context of national security. That it was felt necessary to make such explicit provision in a statute, the first draft of which was published before the decision in Privacy/GreenNet

114 Intelligence and Security Committee (n 43) [CC].

115 Ibid $[\mathrm{XX}]$.

116 Subject to the amendments contained in Investigatory Powers Act 2016, s 251, and discussed further below.

117 IPA 2016, s 99(2). For the definition of 'equipment', see s 135(1), which provides that it means 'equipment producing electromagnetic, acoustic or other emissions or any device capable of being used in connection with such equipment'. This definition was described by Liberty during the passage of the Act as 'unfathomably open-ended': see Liberty, Written Evidence to the Joint Committee on the Draft Investigatory Powers Bill (IPB 0143) [92]. The same might be said of 'communication', which includes 'anything comprising speech, music, sounds, visual images or data of any description' and 'signals serving either for the impartation of anything between persons, between a person and a thing or between things or for the actuation or control of any apparatus' (s 135(1)). For the definition of 'equipment data', see s 100.

118 IPA 2016, s 102(1)(a). The grounds on which a warrant might be necessary are found in s 102(5): they also include the interests of the UK's 'economic well-being' insofar as those interests are relevant to national security.

119 IPA 2016, s 102(1)(b).

120 Ibid s 98(2).

$121 \mathrm{Ibid}, \mathrm{s} 102(1)(\mathrm{d})$. The Judicial Commissioners must apply 'the same principles as would be applied by a court on an application for judicial review' in reviewing the decisions as to necessity and proportionality: IPA 2016, s 108(1) and (2). This mechanism (the so-called 'double lock'), which applies to many other powers in the IPA 2016, was the source of much controversy during the passage of the Act, particularly as to the question of whether it was equivalent to 'true' judicial authorisation, or represented some lesser form of judicial control of warrants. It would nevertheless seem to fulfil any requirement imposed by Article 8 ECHR that surveillance be subject to prior judicial authorisation.

122 IPA 2016, s 101. 
was handed down, shows again how unconvincing was the IPT's decision as to the correct interpretation of the 1994 Act. Targeted EI warrants may be granted also - under similar conditions - to the Chief of Defence Intelligence ${ }^{123}$ and - under less similar conditions $^{124}$ - to law enforcement officers (in which case they are issued not by a Secretary of State but by the relevant 'law enforcement chief'). ${ }^{125}$ These too may be thematic. To that extent, powers Lord Browne-Wilkinson thought better suited to the world of Smiley's People have been regularised within the 'every day life of policing'.

The 2016 Act, however, does more than simply give explicit basis to those (thematic) warrants already employed by the SIAs. It also authorises 'bulk' EI, by which is meant EI 'not targeted against particular person(s), organisation(s) or location(s) or against equipment that is being used for particular activities.'. ${ }^{126}$ It was clarified, during the passage of the 2016 Act (when the government, prompted by a report of the Joint Committee on the Investigatory Powers Bill, published its operational case for the bulk powers), that the distinction between targeted and bulk warrants is as follows:
A bulk EI warrant is likely to be required in circumstances where the Secretary of State or Judicial Commissioner is not be [sic] able to assess the necessity and proportionality to a sufficient degree at the time of issuing the warrant ... This might be for example where the purpose of the operation is target discovery and the security and intelligence agencies do not know in advance the identity of the new subjects of interest who threaten the security of the UK and its citizens.

That is, bulk EI warrants fill the space beyond the outer limit of targeted warrants, which is the same as exists on section 5 ISA 1994 warrants. A bulk EI warrant is a general warrant in perhaps the truest sense - general as to both the persons and property to whom it applies, with no individualised requirement of necessity or proportionality imposed. Such a thing is no less pernicious simply because the particular form of property interference which it authorises is limited to that of interference with equipment. Besides being limited to the SIAs, the conditions for the granting of a bulk EI warrant differ in two key ways. First, the Secretary of State must be satisfied that the 'operational purposes' for which the material collected will be examined are necessary (as is its examination). ${ }^{127}$ Second, as with

123 Ibid s 104.

124 Ibid s 106. Targeted EI warrants are available to law enforcement officers for the purpose of preventing or detecting serious crime, but also for various other purposes around preventing or mitigating death or damage to health: s 106(3).

125 Only on publication of the draft Bill was it admitted that the police already carried out CNE, under the thin authority of s 93 of the Police Act 1997; the IPA 2016 amends the 1997 Act so as to prevent its use for the purpose of obtaining communications, private information, or equipment data: $\mathrm{s} 14$. This does not, of course, prevent it being used for other forms of CNE.

126 Draft Investigatory Powers Bill 2015: Explanatory Notes, 83. Bulk CNE was raised in the Privacy/GreenNet case, though the IPT reserved for consideration 'on particular facts and when questions of jurisdiction are examined, whether an individual complainant might be able to mount a claim' regarding the use of s 7 of the 1994 Act for that purpose: [2016] UKIP Trib 14_85-CH, [63]. See also above (n 78): in the application to the European Court of Human Rights mentioned there, the question of bulk CNE under the 1994 Act can be expected to figure prominently. What is said by the Strasbourg Court - particularly as regards the application of the ECHR to extra-territorial CNE - will be significant for any assessment of the Conventioncompatibility of bulk EI under the 2016 Act.

127 IPA 2016, s 178(d). The operational purposes specified in a bulk EI warrant restrict the examination of the material obtained thereunder. They must be chosen from amongst those found in a list maintained by the heads of the SIAs, to which new operational purposes cannot be added except with the authority of the Secretary of State, and a copy of which must be given to the Intelligence and Security Committee at quarterly intervals, and which must be reviewed by the Prime Minister annually: ISA 2016, s 183(5), (7), (9) and (11). The Secretary of State can approve the addition of an operational purpose to the list only if satisfied that 'the operational purpose is specified in a greater level of detail' than the purposes for which a bulk EI warrant may be sought: IPA 2016, s 183(8). Given the breadth of those purposes, this is not much of a hurdle. 
bulk interception warrants under both RIPA 2000 and the IPA 2016,128 the availability of warrants for bulk EI reflects the geographic separation noted above, being limited to the acquisition of 'overseas-related' material. ${ }^{129}$ Such warrants, however, (again following a pattern set by RIPA 2000) ${ }^{130}$ also authorise 'any conduct which it is necessary to undertake in order to do what is expressly authorised by the warrant', including (most importantly) the acquisition of data, communications, or information relating to people who are not outside Britain. ${ }^{131}$ The effect of that provision is to potentially undermine the implicit geographical logic of Entick noted above.

In his review of the operational case for the bulk powers under the 2016 Act, David Anderson QC (the Independent Reviewer of Terrorism Legislation) described bulk EI as 'a fast-developing alternative to bulk interception'132 and concluded that, though 'an operational case for bulk EI has been made out in principle', there was required 'very considerable caution', not least because of the untried nature of bulk EI and its ability to recover data which has never been sent anywhere. ${ }^{133}$ This last point recalls some of the dicta from the general warrant cases quoted above and the fact that a person's papers are his 'dearest property'. There is in the UK a long history of communications being intercepted, whether in the post office (including when telephone exchanges were sited there) ${ }^{134}$ or elsewhere, with the relevant authority found in the murky depths of the history of the Royal Prerogative, ${ }^{135}$ or under the Interception of Communication Act 1985 and, later, RIPA 2000. Powers of EI - both targeted and bulk - are not, however, limited to communications in the sense of things communicated by one person to another, but apply also to 'stored communications' which, once the relevant definitions in the IPA 2016 are pieced together, reveals itself to be more or less anything found upon one's computer. ${ }^{136}$ This is a qualitatively different, and in many ways more intrusive, power than that of intercepting only one communicate to another. ${ }^{137}$ If papers were once one's 'dearest property', then how much dearer - how much more sensitive - the contents of one's hard drive?

Reflecting this, there exist certain safeguards on the use of material obtained via bulk EI, which work to ensure that the powers in question are not used to bypass the

128 RIPA 2000, s 16(2); IPA 2016, s 136.

129 IPA 2016, s 176(1)(c), (2) and (3).

130 RIPA 2000, s 5(6).

131 IPA 2016, s 176(5).

132 David Anderson QC, Report of the Bulk Powers Review (Cm 9326 August 2016) [7.33].

133 Ibid [7.37].

134 On this point, see Malone v Commissioner of Police of the Metropolis (No 2) [1979] Ch 344. For a discussion of the history of telephone interception, see Patrick Fitzgerald and Mark Leopold, Stranger on the Line: Secret History of Phone Tapping (Bodley Head 1987).

135 See the Report of Committee of Privy Councillors, Interception of Communications (Cmnd 283 1957) ('the Birkett report').

136 In relation to targeted interference, see IPA 2016, s 99(6) and (8) (the latter of which defines 'stored communication' as a communication 'stored in or by a telecommunication system (whether before or after its transmission)'); s 261(13) (defining a 'telecommunication system' as 'a system (including the apparatus comprised in it) that exists (whether wholly or partly in the United Kingdom or elsewhere) for the purpose of facilitating the transmission of communications by any means involving the use of electrical or electromagnetic energy'); s 261(2) (defining 'communications' to include 'anything comprising speech, music, sounds, visual images or data of any description' and 'signals serving either for the impartation of anything between persons, between a person and a thing or between things or for the actuation or control of any apparatus'); and s 263(1) (defining 'apparatus' as including 'any equipment, machinery or device (whether physical or logical) and any wire or cable').

137 See also the discussion of the intrusiveness of EI by Liberty (n 117) [75]-[78]. 
requirements of a targeted EI warrant. Specifically, material obtained through bulk EI (other than equipment data or non-private information), ${ }^{138}$ may not be selected for examination if:

... any criteria used for the selection of the material for examination are referable to an individual known to be in the British Islands at that time, and the purpose of using those criteria is to identify protected material consisting of communications sent by, or intended for, that individual or private information relating to that individual. ${ }^{139}$

This implies, conversely, that, where the purpose of using those criteria in question is to identify material which is not 'protected material' (defined to mean, roughly, private information and the content of communications), ${ }^{140}$ then it can take place without additional authorisation. If it is desired to select information for examination in breach of this restriction, the SIAs must seek a 'targeted examination warrant' which 'authorises the person to whom it is addressed to carry out the selection of protected material obtained under a bulk EI warrant for examination, in breach of the prohibition' described, ${ }^{141}$ for which the preconditions are equivalent to those for the making of a targeted interference warrant, alongside the requirement that 'the Secretary of State considers that the warrant is or may be necessary to authorise the selection of protected material for examination' in breach of the prohibition. ${ }^{142} \mathrm{~A}$ targeted examination warrant may itself be thematic: though the thematic permissions offered in the Act are fewer than are those relating to targeted EI warrants, they include nevertheless that a targeted examination warrant may relate to:

(a) a particular person or organisation;

(b) a group of persons who share a common purpose or who carry on, or may carry on, a particular activity;

(c) more than one person or organisation, where the conduct authorised by the warrant is for the purpose of a single investigation or operation;

(d) the testing, maintenance or development of capabilities relating to the selection of protected material for examination;

(e) the training of persons who carry out, or are likely to carry out, the selection of such material for examination. ${ }^{143}$

On one hand, the differential treatment of 'domestic' EI and 'foreign' bulk EI may appear an attempt to prevent the acquisition of bulk EI being used to bypass the limitations on the use of the targeted powers. In practice, however, the relationship between targeted and bulk EI may be exactly the opposite, given the availability of thematic targeted EI warrants. Because, as was pointed out by the Intelligence and Security Committee in its report on the Bill, a targeted warrant is 'not limited to an individual piece of equipment, but can relate to all equipment where there is a common link between multiple people, locations or organisations', 144 a thematic warrant can do much - though not, of course, all - of the work a bulk EI warrant might do, but with fewer procedural limitations. That is, targeted

138 IPA 2016, s 193(1)(c) and (9).

139 Ibid s 193(1)(c), (3)(a), and (4).

140 Ibid s 193(9) and s 198(1) (defining 'private information' to mean 'relating to a person's private or family life') and s 177 (defining 'equipment data').

141 Ibid s 99(9).

142 Ibid s 102(3).

143 Ibid s 101(2).

144 Intelligence and Security Committee, Report on the Draft Investigatory Powers Bill (HC 795, 2015-16) [14]. 
EI warrants are available to parties other than the SIAs (bulk EI warrants are not), do not require a national security purpose (bulk EI warrants do), and can be domestic-focused (which bulk EI warrants cannot be). The Independent Reviewer of Terrorism Legislation suggested in evidence to the Bill Committee that the provision for thematic warrants 'effectively import[ed] an alternative means of performing bulk EI, with fewer safeguards'145 and that the government's explanation (that in thematic situations 'the Secretary of State and the Judicial Commissioner are likely to be able to adequately foresee the proposed interferences with privacy in relation to the data to be examined to a sufficient degree, such that the additional access controls under the bulk EI warranty regime are not required') ${ }^{146}$ potentially 'place[s] excessive weight on the discretion of decision-makers'. ${ }^{147}$ The Draft Code of Practice, which will apply to thematic EI warrants under the 2016 Act, states that ' $t$ t] he warrant application must also contain as much information as possible and be as specific as possible in relation to the equipment to be covered' on the basis that, as well as 'fully informing the issuing authority, this will also assist those executing the warrant so that they are clear as to the scope of what actions and equipment the warrant covers'. ${ }^{148}$ The concepts of necessity and proportionality therefore do significant work in ensuring that there is no misuse of thematic EI warrants and much will depend on the standard of review applied by Judicial Commissioners to expressions of the Secretary of State's belief that a particular thematic warrant meets the requirements of necessity and proportionality prescribed by the 2016 Act. There are no statutory limitations on EI as regards confidential information generally, though special protections are offered to legally privileged material, both in terms of its acquisition and its examination, requiring an identification of the 'exceptional and compelling circumstances' which make it necessary, ${ }^{149}$ and to journalistic material. ${ }^{150}$ These latter are, however, significantly weaker than the equivalent protections in PACE 1984. ${ }^{151}$

The IPA 2016 does not otherwise regulate interferences with property, which will continue to take place in accordance with the ISA 1994 and the Police Act 1997. The 1994 Act will continue to contain general powers, there having been no moves towards - as was recommended by the ISC - setting out the agencies' powers 'clearly and unambiguously' so as to avoid the impression of giving them a 'blank cheque'. 152 The IPA 2016 makes the use of EI warrants by the SIAs mandatory when taking action which would otherwise be contrary to the Computer Misuse Act 1990 for the purpose of 'obtaining communications, private information or equipment data'. ${ }^{153}$ This restriction applies, however, only where 'there is a British Islands' connection ${ }^{154}$ and so, where there is not, there would appear to exist what the IPT has called in another context 'two lawful

145 David Anderson QC, Written Evidence to the House of Commons Public Bill Committee on the Investigatory Powers Bill (IP B46, 24 March 2016) [5].

146 HM Government, Operational Case for Bulk. Powers (March 2016) [8.6].

147 Anderson (n 145) [5].

148 EI Draft Code of Practice (spring 2016) [4.18].

149 IPA 2016, s 112(4)(a) (targeted EI warrants) and s 194 (bulk EI warrants). For elaboration of that phrase, see s $112(6)$ and s 194(5).

150 Ibid ss 13,114 , and $129(8)$.

151 Cf Police and Criminal Evidence Act 1984, Schedule 1, which makes provision for notification of the subject of a warrant and interpartes argument before a judge prior to the granting of a warrant where there are reasonable grounds for believing that there is 'excluded material' (which includes certain 'journalistic material') or 'special procedure material' (which includes other 'journalistic material') on premises named in a search warrant.

152 Intelligence and Security Committee (n 43) [MM].

153 IPA 2016, s 13.

154 Ibid s 13(1)(b). 
routes'155 for the conduct of EI - the IPA not being directly incompatible with the 1994 Act, it seems unlikely that the later Act will be held to have impliedly repealed the earlier one to the extent it permits the carrying out of EI. ${ }^{156}$ Though the IPA 2016 amends the 1994 Act so as to put MI6 and GCHQ in the same position as MI5 as regards their ability to carry out property interferences in support of the prevention or detection of serious crime in the UK, 157 the 'British Islands connection' rule prevents that change being used to bypass limitations contained in the IPA 2016. That does not counter fully the fear once expressed by Hunt and Duffy; other limits in other contexts may nevertheless be bypassed on this basis.

If EI must now (subject to the exceptions described) take place only under the new IPA 2016 powers, it is impossible to know exactly what activities might (continue to) take place under the residual ISA 1994 powers of property interference. In the first place, it will include the sort of breaking and entering which Peter Wright had in mind when he wrote in Spycatcher that he and his colleagues had 'bugged and burgled our way across London at the State's behest, while pompous bowler-hatted civil servants in Whitehall pretended to look the other way'; ${ }^{\prime}{ }^{2}$ other elements will be interference with property (including EI) or wireless telegraphy where the purpose is not to acquire communications, or equipment data, or other information. ${ }^{159}$ That is, $\mathrm{CNE}$ which seeks not to acquire data but simply to destroy or otherwise manipulate the functioning of electronic systems can still be authorised under the 1994 Act. What is clear, therefore, is that the decision of the IPT - as to the requirements that section 5 warrants must meet, as well as to the ability of warrants to conform with the ECHR even as regards the heightened requirements which apply to norms permitting surveillance - ensures that the scope for legitimate use of these residual powers is far greater than would otherwise have been the case.

\section{Conclusion}

The common law's opposition to general warrants does not logically preclude their statutory existence. On the contrary, legislation which empowers the making of such warrants is an affirmation of the decisions in Entick $v$ Carrington and those cases which share the distaste expressed therein for warrants which are general as to the property and, especially, the persons to which they apply. Nevertheless, the decision of the IPT in Privacy/GreenNet indicates that the common law has (for now at least) lost some of its suspicion of broad powers of property interference, in a way which conflicts more generally with the spirit of those cases. General terms in the ISA 1994 have been held to be capable of justifying interferences with property even where specific details of the property in question are not found in the warrant. This approach might be justified by reference to the considerations of national security which are reflected in the statutory powers - though a close reading of Entick $v$ Carrington would seem to require a suspicion also of such appeals to state necessity - but the powers of the SIAs have never been limited to national security ends and the domestication of the powers to interfere with property by the Security Service Act 1996 and the IPA 2016 for purposes related not to national security but to the prevention and detection of serious crime means that the

155 Privacy International v Secretary of State for Foreign and Commonwealth Affairs [2016] UKIP Trib 15_110-CH, [57].

156 For the rule of implied repeal, see Ellen Street Estates Ltd v Minister of Health [1934] 1 KB 590 and the discussion of it in Adam Tomkins, Public Law (Oxford University Press 2003) 107.

157 IPA 2016, s 251, amending ss 3 and 5 of the ISA 1994.

158 Peter Wright, Spycatcher: The Candid Autobiography of a Senior Intelligence Officer (Viking 1987) 54.

159 An example given by a commentator on the Investigatory Powers Bill (the identity of whom I can no longer trace) is that of disabling burglar alarms in order to facilitate entry into property. 
broad powers now recognised as existing are liable to be invoked even outside that particular context. Some of the effect of the IPT's decision is superseded by the 2016 Act's creation of powers of EI which are unambiguously thematic, accompanied by new and (even) more intrusive bulk EI powers. In this sense, we are perhaps closer to truly general warrants than at any time since Entick was decided, with the relatively limited form of the property interference empowered doing little to dispel the impression that what has happened is in many ways equivalent to what was feared by Lord Camden: 'the secret cabinets and bureaus of every subject in this kingdom' have been 'thrown open to the search and inspection of a messenger' - though, given the geographic distinctions at work, this is truer of thematic than of bulk warrants. Alongside these new powers, there stand also the powers under the 1994 Act, as expanded in 1996 and 2016 (both s 5 and $\mathrm{s} 7$ of which permit property interferences which are authorised thematically though not bulk interferences). The common law may well have set its face against general warrants, but statute now grounds a series of powers which are at least as damaging to the sanctity of property and - more importantly - the privacy of the individual which property helps to secure. 
